\title{
44. OXYGEN AND HYDROGEN ISOTOPE EXCHANGE REACTIONS BETWEEN SEA WATER AND OCEANIC BASALTS FROM LEGS 51 THROUGH 53
}

\author{
H. Friedrichsen and S. Hoernes, University of Tübigen, Tübigen, Germany
}

\section{INTRODUCTION}

Oxygen isotope investigations on oceanic crust material provide evidence for the intense exchange of oxygen between ocean water and the basement. Sea water has percolated the ocean crust and equilibrated its isotopes with silicates. The extent of exchange between the water and the basement is presently not well known. In the upper 600 meters of the basement (i.e., upper one-tenth of the oceanic crust), there is no substantial decrease in the extent of this isotope exchange reaction with depth. Measurements on Leg 37 intrusive rocks, which might be part of Layer 3, have shown that up to 25 per cent of the total oxygen in these rocks is sea-water oxygen.

Previous studies (Hoernes and Friedrichsen, 1977, 1978; Hoernes et al., 1978; Muehlenbachs and Clayton, 1972, 1976) proved that there are two major events during the cooling of the crust which are accompanied by an isotope exchange between both phases. The first reaction occurs at magmatic temperatures which yield a decrease of the $\delta^{18} \mathrm{O}$ values in the silicates and an increase of the $\delta^{18} \mathrm{O}$-values of the fluid phase (the water). Many phenocrysts of plagioclase, olivine, and pyroxene (as well as the titanomagnetites) from the groundmass are depleted in their $\delta^{18} \mathrm{O}$-values as a result of this type of reaction. The temperatures for this reaction have been calculated from $\Delta^{18} \mathrm{O}$-fractionations between coexisting minerals, and they are in good agreement with the solidus temperatures of the magma. A relationship between these temperatures and the amount of sea water which was present during the crystallization has been derived from $\mathrm{O}$-isotope data by Hoernes and Friedrichsen (1977) and Hoernes et al. (1978). In general, 0 to 3 weight per cent ocean water was present during the crystallization of the magma, but some intrusive rocks studied from Leg 37 have exchanged isotopes with up to 10 weight per cent water before the magma crystallized.

A second significant reaction between the basalts and the sea water occurs at low temperatures, between 0 and $100^{\circ} \mathrm{C}$ : clay minerals and zeolites with high $\delta^{18} \mathrm{O}$-values are formed. Mainly the (glassy) groundmass is affected during this type of reaction. Unaltered phenocrysts and the magnetites have preserved the original magmatic $\delta^{18} \mathrm{O}$-values. In general, no subsolidus exchange of oxygen has been observed.

Low-temperature reactions of the basalts cause an increase of the $\delta^{18} \mathrm{O}$-value in the alteration products and a decrease of the $\delta^{18} \mathrm{O}$-value in the water which equilibrated with the silicates. Isotope balance calculations on the basalts indicate that about 10 per cent of the basalts have reacted with the water at low temperatures, yielding an overall in- crease of the mean $\delta$-value of $2.2 \%$ for all basalts from Legs 37,45 , and 46.

The high-temperature reaction between the basalts obviously happened at the ridge crest. However, it is not well known when the low-temperature alterations occurred. Interpretation of heat flow data by Wolery and Sleep (1976) indicates that the major hydrothermal circulation within the basement also occurs near the ridge zones and ceases after about 10 m.y.

All cored basalts which have been investigated to date are young crustal basalts ( 0 to $10 \mathrm{~m} . \mathrm{y}$.). During Legs 51 through 53, 100-m.y.-old crust was cored. It is the purpose of this study to compare the extent of low-temperature alteration between this old oceanic crust material and the basalts from Legs 37,45 , and 46.

\section{EXPERIMENTAL PROCEDURES}

The experimental procedures for mineral separation, preparation of the $\mathrm{CO}_{2}$ from the silicates, and the isotope analysis have been published elsewhere (Hoernes and Friedrichsen, 1977). Hydrogen was liberated from samples which had been dried at $150^{\circ} \mathrm{C}$ overnight in vacuum. All oxygen and hydrogen isotope data are reported on the SMOW scale. The analytical reproducibility was $\pm 0.15 \%$ for the $\delta^{18} \mathrm{O}$-values and $\pm 2 \%$ for the $\mathrm{D} / \mathrm{H}$ ratios. Tables 1 and 2 provide the finding of these investigations for $\delta^{18} \mathrm{O}$ and whole-rock values, and for $\delta^{18} \mathrm{O}$ mineral data, respectively,

\section{RESULTS AND DISCUSSION}

\section{Low-Temperature Alteration Effects on Oxygen Isotopes}

In Figures 1 and 2, all $\delta^{18} \mathrm{O}$-values of the whole rocks from Holes 417D and 418A are plotted versus depth. Unaltered basalts, which have not interacted with water, have typical $\delta^{18} \mathrm{O}$-values of $+5.7 \pm 0.2 \%$ (Muehlenbachs and Clayton, 1972; Muehlenbachs, 1977). The $\delta^{18} \mathrm{O}$-data show that more than 70 per cent of all rocks are enriched in ${ }^{18} \mathrm{O}$. Values of $+22.5 \%$ for $\delta^{18} \mathrm{O}$ have been measured. If we assume that the alteration products (the smectites) have a $\delta^{18} \mathrm{O}$-value of $+25 \%$ on the SMOW scale and that an unaltered basalt has a $\delta^{18} \mathrm{O}$-value of $+5.7 \%$, then 11.4 per cent of the total basalts have reacted with sea water yielding smectite. More than 5 weight per cent of the oxygen in the basalts is sea-water oxygen. Again, there is no relationship between depth and extent of smectite formation in the basalts which have been recovered from the upper 500 meters of the oceanic crust. High $\delta^{18} \mathrm{O}$-values (which means high oxygen exchange between the water and the basalts) 
TABLE 1

$\delta^{18} \mathrm{O}$ and $\delta \mathrm{D}$ Whole-Rock Values From Sites 417 and 418

\begin{tabular}{lrr}
\hline $\begin{array}{c}\text { Sample } \\
\text { (Interval in cm) }\end{array}$ & $\delta^{18} \mathrm{O}$ & \multicolumn{1}{c}{$\delta \mathrm{D}$} \\
\hline Hole 417A & & \\
$26-5,119-124(\# 11)$ & & -114 \\
$34-2,88-93(\# 8 \mathrm{~A})$ & & -119 \\
$34-5,43-50(\# 2 \mathrm{~B})$ & 10.3 & -99 \\
$36-2,90-95(\# 4 \mathrm{~B})$ & & -123 \\
$37-1,37-43(\# 1 \mathrm{~B})$ & & -116 \\
$38-3,75-79(\# 1)$ & -108 \\
$38-6,81-86(\# 3)$ & -110 \\
$41-3,92-97(\# 2 \mathrm{~b})$ & -110 \\
$42-7,9-13(\# 1 \mathrm{a})$ & -91 \\
$44-2,13-17$ (\#1A) & -108
\end{tabular}

\section{Hole 417D}

\begin{tabular}{lrr}
$22-1,96-102$ (\#7) & & -93 \\
$22-4,24-28$ (\#1A) & & -102 \\
$22-6,143-148$ & 8.7 & -108 \\
$26-1,40-44$ (\#4) & 9.9 & -101 \\
$26-6,87-91$ (\#4B) & & -115 \\
$27-5,68-74$ (\#3) & 9.0 & -122 \\
$28-1,44-50$ & & -100 \\
$28-6,111-117$ & 8.9 & -109 \\
$29-2,50-54$ & & -118 \\
$29-6,8-13$ & & -110 \\
$30-7,90-96$ & & -121 \\
$31-2,98-102$ & & -126 \\
$32-2,34-39$ & & -114 \\
$33-2,23-28$ (\#1B) & 6.9 & -117 \\
$34-2,34-40$ (\#1B) & 7.7 & -117 \\
$34-5,66-71$ (\#1D) & 7.5 & -114 \\
$35-4,27-33$ (\#3A) & & -120 \\
$36-2,89-94$ (\#2B) & & -92 \\
$36-4,34-39$ (\#2A) & & -120 \\
$37-4,8-15$ (\#1) & 7.2 & -118 \\
$37-6,65-70$ (\#4) & & -131 \\
$38-2,86-99$ (\#8A) & 9.1 & \\
$38-4,106-111$ (\#5A) & 7.2 & \\
$39-3,95-101$ (\#2B) & & -121 \\
$39-4,60-66$ (\#2) & & -115 \\
$41-4,21-27$ (\#1B) & & -130 \\
$41-6,93-99$ (\#4A) & & -107 \\
$42-1,10-16$ (\#1B) & 10 & -114 \\
$42-2,98-104$ (\#4B) & 7.7 & -105 \\
$42-3,7-11$ (\#1) & & -123 \\
$42-6,91-96$ (\#4) & & -112 \\
$43-3,52-57$ (\#1D) & & -108 \\
$43-6,57-62$ (\#4B) & & -103 \\
$44-1,54-59$ (\#3A) & & -116 \\
$44-4,75-79$ (\#6) & & -99 \\
$45-1,5-8$ (\#1A) & & -113 \\
$45-2,48-53$ (\#2D) & 7.8 & -119 \\
$48-5,23-25$ & 8.6 & -118 \\
$52-3,138-140$ & 6.5 & -130 \\
$54-3,112-114$ & 7.3 & -122 \\
$60-5,68-70$ & 12.1 & -82 \\
$63-1,117-119$ (\#2e) & 7.1 & -139 \\
$64-4,20-22$ (\#1a) & 7.0 & -146 \\
$65-1,123-125$ (\#2a) & 6.3 & -118 \\
$68-1,95-97$ (\#2a) & 6.8 & -138 \\
$69-1,130-132$ & 6.3 & -136 \\
\hline & & \\
\hline
\end{tabular}

have been measured on samples from margins between different lithologic units or different flows.

The extent of alteration of the 100-m.y.-old crust does not differ from the alteration of the young crust (with an age of $10 \mathrm{~m} . \mathrm{y}$.) from Legs 45 and 46 and the very young mate-
TABLE 1 - Continued

\begin{tabular}{|c|c|c|}
\hline $\begin{array}{c}\text { Sample } \\
\text { (Interval in } \mathrm{cm} \text { ) }\end{array}$ & ${ }^{18} \mathrm{O}$ & $\delta \mathrm{D}$ \\
\hline \multicolumn{3}{|l|}{ Hole 418A } \\
\hline $18-4,134-136$ & 6.4 & -120 \\
\hline $18-4,67-69(\# 1 c)$ & 8.6 & \\
\hline $19-4,9-11$ & 6.0 & -123 \\
\hline $20-3,105-107(\# 3 c)$ & 7.3 & -134 \\
\hline $42-4,70-72(\# 4 b)$ & 7.9 & -126 \\
\hline $45-1,80-82(\# 5 \mathrm{e})$ & 7.2 & -137 \\
\hline $46-3,90-92(\# 6 c)$ & 7.6 & -126 \\
\hline 49-2, 94-97 (\#8a) & & -122 \\
\hline $50-4,128-130(\# 10 a)$ & 7.6 & -116 \\
\hline $51-2,22-31(\# 1 b)$ & 7.2 & -124 \\
\hline $52-7,86-89$ & 6.8 & -121 \\
\hline $54-1,120-122$ (\#9) & 6.8 & -121 \\
\hline $56-3,12-16(\# 1 b)$ & & -101 \\
\hline $58-1,126-129$ (\#8a) & 12.0 & -109 \\
\hline $59-5,120-125(\# 3 c)$ & 10.2 & -121 \\
\hline $60-4,55-58(\# 1 f)$ & 8.3 & -135 \\
\hline $60-4,98-100(\# 1 \mathrm{j})$ & 8.0 & -106 \\
\hline $61-1,84-87(\# 5 b)$ & 6.4 & -112 \\
\hline $62-1,140-142(\# 5)$ & 8.0 & -110 \\
\hline $63-3,90-93(\# 6)$ & & -106 \\
\hline $64-4,37-39$ (\#2b) & 8.4 & -110 \\
\hline $65-2,83-87(\# 5 b)$ & 8.2 & -142 \\
\hline $65-3,32-34(\# 3)$ & 8.1 & -132 \\
\hline $66-4,44-45(\# 2)$ & 6.4 & -169 \\
\hline $69-1,143-146(\# 2 c)$ & 6.5 & -154 \\
\hline $70-4,95-97(\# 3 b)$ & 7.2 & -140 \\
\hline $72-4,58-61(\# 1 f)$ & 6.6 & -169 \\
\hline $73-2,14-17(\# 2)$ & 21.2 & -102 \\
\hline $73-5,62-65$ (\#1f) & 7.1 & -172 \\
\hline $75-1,122-124(\# 4 c)$ & 12.3 & -73 \\
\hline $75-1,138-140(\# 4 c)$ & 15.8 & -86 \\
\hline $75-3,129-131(\# 8)$ & 10.2 & -142 \\
\hline $79-1,84-86(\# 7 a)$ & 6.8 & \\
\hline $79-4,84-88(\# 2 c)$ & 6.4 & -86 \\
\hline $83-4,99-101$ & 6.3 & -49 \\
\hline $84-1,38-40(\# 2 c)$ & & -116 \\
\hline $84-3,53-54$ (\#1d) & 9.8 & -98 \\
\hline $84-4,31-32(\# 2)$ & 7.4 & -142 \\
\hline $86-5,58-62(\# 4 a)$ & 7.6 & -132 \\
\hline $86-6,32-34$ (\#2b) & 7.4 & -133 \\
\hline
\end{tabular}

rial of Leg 37 (Hoernes and Friedrichsen, 1977, 1978; Hoernes et al., 1978; Muehlenbachs, 1977).

The circulation system was probably sealed at a very early stage and the major crust ocean water exchange reactions occur probably near the ridges.

\section{Low-Temperature Alteration Effects on Hydrogen Isotopes}

Because the samples were dried at $150^{\circ} \mathrm{C}$ in a vacuum before treatment, all hydrogen which has been analyzed is $\mathrm{OH}$-bonded hydrogen in minerals. Figures 3 and 4 plot depth versus $\mathrm{D} / \mathrm{H}$ ratios of whole-rock samples from Holes $417 \mathrm{D}$ and 418A, respectively. Both diagrams show a similar pattern. Samples from the upper 300 meters yield more uniform $\delta \mathrm{D}$-values between -90 and $-130 \%$. In samples from greater depths, we observe a wider spread of the data from -170 to $-50 \%$. $\delta \mathrm{D}$-values of -90 to $-130 \%$ are expected for clay minerals which have been formed in equilibrium with sea water at low temperatures (Suzuoki and Epstein, 1976). Higher $\delta D$-values of $-50 \%$ have been analyzed in serpentines (Leg 45) which were formed at elevated temperatures (up to $400^{\circ} \mathrm{C}$ ). Low $\delta$ D-values of 
TABLE 2

${ }_{\delta}^{18} \mathrm{O}$ Mineral Data

\begin{tabular}{|c|c|c|c|c|c|}
\hline $\begin{array}{c}\text { Sample } \\
\text { (Interval in } \mathrm{cm} \text { ) }\end{array}$ & Plag. & Clinopyr. & Mag. & $\Delta^{18} \mathrm{O}$ & $\mathrm{T}\left({ }^{\circ} \mathrm{C}\right)$ \\
\hline \multicolumn{6}{|l|}{ Hole 417A } \\
\hline $37-1,37-43(\# 1 B)$ & 6.2 & 4.7 & & & \\
\hline $38-3,75-79(\# 1)$ & $\begin{array}{l}\text { pheno: } 6.0 \\
\text { ground: } 5.6\end{array}$ & 5.0 & & & \\
\hline $40-3,25-29(\# 1)$ & $\begin{array}{l}\text { pheno: } 6.35 \\
\text { ground: } 6.2\end{array}$ & $\begin{array}{l}\text { pheno: } 5.95 \\
\text { ground: } 5.5\end{array}$ & & & \\
\hline $42-7,9-13(\# 1 a)$ & $\begin{array}{l}\text { smectite }= \\
\text { plag. } 23=0.5\end{array}$ & 5.4 & & & \\
\hline \multicolumn{6}{|l|}{ Hole 417D } \\
\hline $22-6,143-148$ & 6.7 & & & & \\
\hline $26-1,40-44(\# 4)$ & 6.1 & & & & \\
\hline $27-5,68-74(\# 3)$ & 9.7 & & & & \\
\hline $28-6,111-117$ & 5.3 & & & & \\
\hline $29-2,50-54$ & 5.8 & & & & \\
\hline $30-7,90-96$ & 5.7 & $\begin{array}{l}4.5 \\
5.5\end{array}$ & & & \\
\hline $\begin{array}{l}32-2,34-39 \\
33-2,23-28(\# 1 B)\end{array}$ & $\begin{array}{l}5.25 \\
5.35\end{array}$ & 5.5 & 2.9 & $\mathrm{p}-\mathrm{m} 2.45$ & 1010 \\
\hline $34-2,34-40$ (\# 1B) & 5.8 & & 2.7 & p pon 2.70 & 1010 \\
\hline $34-5,66-71$ (\#1D) & 5.45 & & & & \\
\hline $37-4,8-15(\# 1)$ & 5.5 & 5.35 & & & \\
\hline $38-2,86-99(\# 8 A)$ & 8.4 & & & & \\
\hline $38-4,106-111(\# 5 A)$ & 5.5 & 5.0 & & & \\
\hline $39-4,60-66(\# 2)$ & 5.75 & 5.0 & & & \\
\hline $42-1,10-16(\# 1 B)$ & 5.6 & 5.2 & & & \\
\hline $42-2,98-104(\# 4 B)$ & 5.45 & 4.85 & & & \\
\hline $43-3,52-57$ (\#1D) & 6.6 & 5.3 & 4.1 & $\mathrm{p}-\mathrm{m} 2.5$ & 1000 \\
\hline $45-2,48-53(\# 2 D)$ & 6.3 & 5.3 & 3.9 & $\mathrm{p}-\mathrm{m} 2.4$ & 1020 \\
\hline $48-5,23-25$ & 6.45 & 5.6 & 3.9 & $\mathrm{p}-\mathrm{m} 2.55$ & 990 \\
\hline $52-3,138-140$ & $\begin{array}{r}\text { pheno: } 5.9 \\
\text { ground: } 5.9\end{array}$ & 5.5 & 3.6 & $\mathrm{p} \cdot \mathrm{m} 2.3$ & 1040 \\
\hline $54-3,112-114$ & pheno: 5.75 & pheno: 5.4 & & & \\
\hline & ground: 5.55 & ground: 5.5 & & & \\
\hline $63-1,117-119(\# 2 \mathrm{e})$ & 5.9 & 5.5 & & $\begin{array}{c}\text { glass (altered): } \\
15.6\end{array}$ & \\
\hline $64-4,20-22$ (\#1a) & 5.8 & & & & \\
\hline $65-1,123-125(\# 2 a)$ & 5.8 & & 3.8 & $\mathrm{p}-\mathrm{m} 2.0$ & 1120 \\
\hline $68-1,95-97(\# 2 a)$ & 5.9 & 5.5 & 3.2 & $\mathrm{p}-\mathrm{m} 2.7$ & 960 \\
\hline $69-1,130-132$ & 5.75 & 5.6 & 3.45 & p-m 2.3 & 1040 \\
\hline \multicolumn{6}{|l|}{ Hole 418A } \\
\hline $18-4,67-69(\# \mathrm{Ic})$ & 6.0 & 5.0 & 3.5 & $\mathrm{p}-\mathrm{m} 2.5$ & 1000 \\
\hline $19-4,9-11$ & 5.55 & & & & \\
\hline $18-4,134-136$ & 5.75 & 5.45 & & & \\
\hline $20-3,105-107$ & 5.65 & 5.25 & & & \\
\hline $42-4,70-72(\# 4 b)$ & 5.75 & & & & \\
\hline $45-1,80-82(\# 5 c)$ & $\begin{array}{l}\text { pheno: } 6.05 \\
\text { ground: } 5.6\end{array}$ & & & & \\
\hline $46-3,90-92(\# 6 c)$ & 6.0 & & & & \\
\hline $49-2,94-97(\# 8 a)$ & 5.7 & & & & \\
\hline $51-2,38-41(\# 16)$ & 5.4 & 5.4 & & & \\
\hline $52-4,35-37(\# 2)$ & 6.0 & 5.4 & & & \\
\hline $\begin{array}{l}52-7,86-89, \mathrm{CC} \\
54-1,120-122(\# 9)\end{array}$ & $\begin{array}{l}6.5 \\
5.55\end{array}$ & 5.35 & & & \\
\hline $56-3,12-16(\# 1 b)$ & 5.3 & 5.4 & & & \\
\hline $58-1,126-129(\# 8 \mathrm{a})$ & $\begin{array}{l}\text { smectite }= \\
\text { plag. } 16.9\end{array}$ & & & & \\
\hline $59-5,120-125(\# 3 \mathrm{c})$ & 5.7 & & & & \\
\hline $60-4,98-100$ (\#1f) & 5.4 & & 3.0 & $\mathrm{p}-\mathrm{m} 2.4$ & 1020 \\
\hline $60-4,55-58(\# 11)$ & $\begin{array}{l}\text { smectite } \pm \\
\text { plag. 11.1 }\end{array}$ & & & & \\
\hline $61-1,84-87(\# 5 b)$ & 5.45 & & & & \\
\hline $63-3,90-93(\# 6)$ & 5.95 & & & & \\
\hline $64-4,37-39(\# 2 b)$ & 5.2 & 5.4 & & & \\
\hline $65-3,32-34(\# 3)$ & 5.4 & 5.05 & & & \\
\hline $66-4,44-45(\# 2)$ & 5.5 & 5.45 & & & \\
\hline $69-1,143-146(\# 2 c)$ & 5.75 & 5.5 & & & \\
\hline $70-4,95-97(\# 3 b)$ & 6.15 & 5.6 & 4.0 & p-m 2.15 & 1080 \\
\hline $72-4,58-61(\# 1 f)$ & 5.6 & 5.4 & & & \\
\hline $73-2,14-17(\# 2)$ & $\begin{array}{l}\text { smectite } \pm \\
\text { plag. } 20.5\end{array}$ & & & quartz 24.4 & \\
\hline $73-5,62-65(\# 1 f)$ & 5.9 & 5.3 & & & \\
\hline $74-5,35-39(\# 3 a)$ & 5.55 & 4.85 & & & \\
\hline $75-1,138-140(\# 4 c)$ & 7.0 & 4.9 & & & \\
\hline $75-1,122-124(\# 4 c)$ & 5.35 & & & & \\
\hline $75-3,129-131(\# 8)$ & 7.6 & & & & \\
\hline $79-1,84-86(\# 7 a)$ & 6.1 & 4.1 & & & \\
\hline $79-4,84-88(\# 2 c)$ & 5.5 & 5.3 & & quartz: 22.3 & \\
\hline $83-4,99-101$ & 6.8 & 5.1 & & & \\
\hline $84-3,53-54$ (\#1d) & 6.2 & 5.55 & 3.1 & $\mathrm{p}-\mathrm{m} 3.1$ & 900 \\
\hline $84-4,31-32(\# 2)$ & 6.0 & 5.2 & 3.0 & $\mathrm{p}-\mathrm{m} 3.0$ & 915 \\
\hline $84-1,38-40(\# 2 c)$ & 5.8 & 5.1 & 3.5 & p-m 2.3 & 1040 \\
\hline $86-5,58-62(\# 4 a)$ & 6.0 & & & & \\
\hline $86-6,32-34(\# 2 b)$ & 5.55 & & & & \\
\hline
\end{tabular}

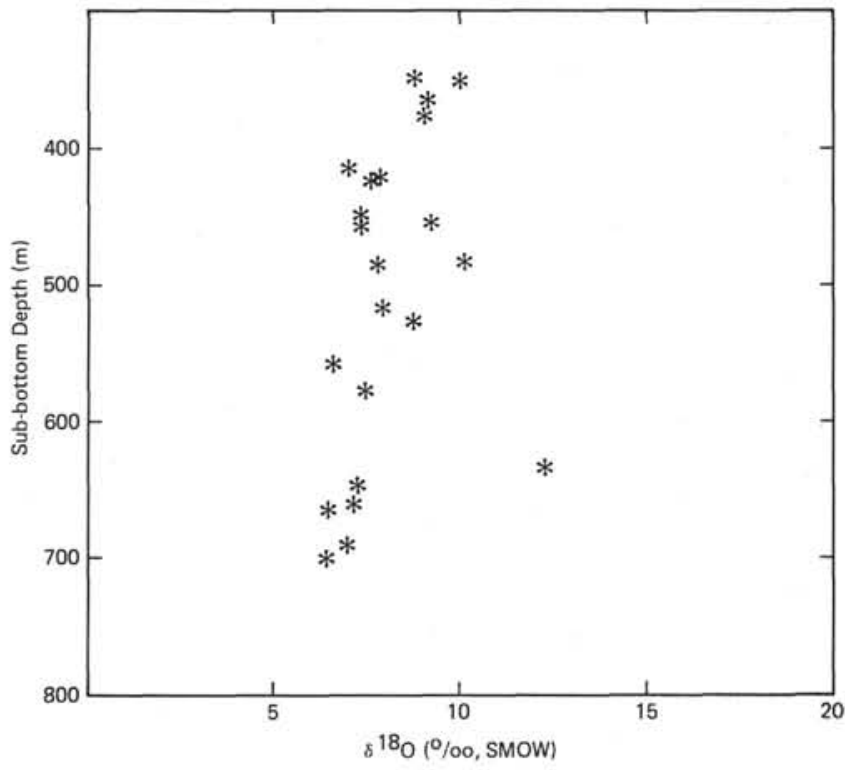

Figure 1. Whole-rock oxygen isotope composition of basalts from Hole 417D.

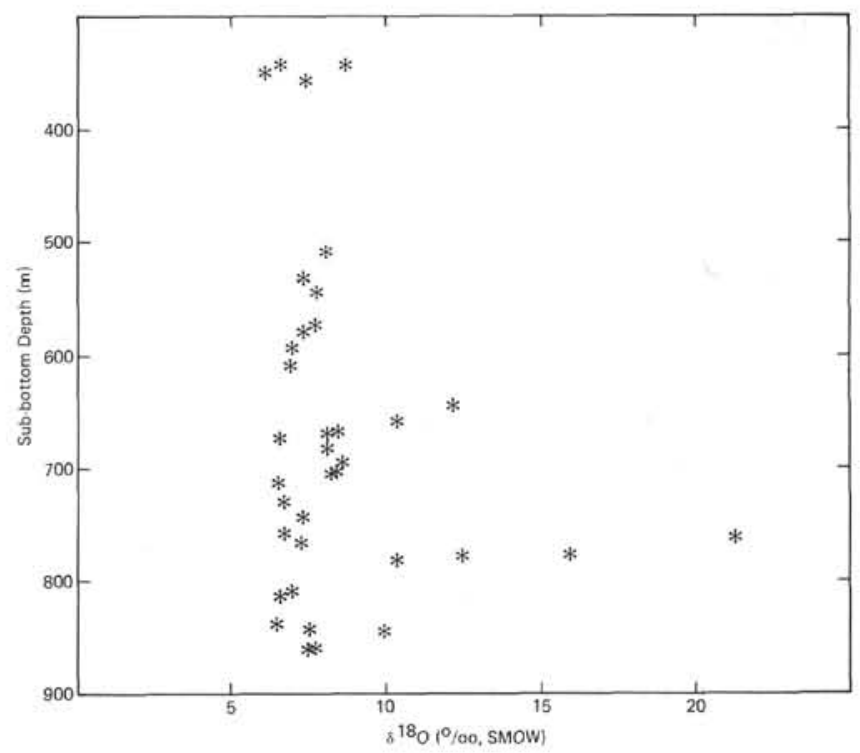

Figure 2. Whole-rock oxygen isotope composition of basalts from Hole 418A. The pronounced increase of the ${ }_{\delta} 180$-values near 800 meters corresponds to the stratigraphic contact of an upper series consisting of sparsely to moderately phyric basalts and a series of different flows in the lower part.

-130 to $-160 \%$ cannot be explained as a result of a simple reaction. Partial dehydration of a clay mineral at elevated temperatures with a pronounced liberation of deuterium-rich water should result in a depletion of deuterium in the residual $\mathrm{OH}$-minerals. There seems to be no significant correlation between $\delta^{18} \mathrm{O}$ and $\delta \mathrm{D}$, as shown in Figure 5. 


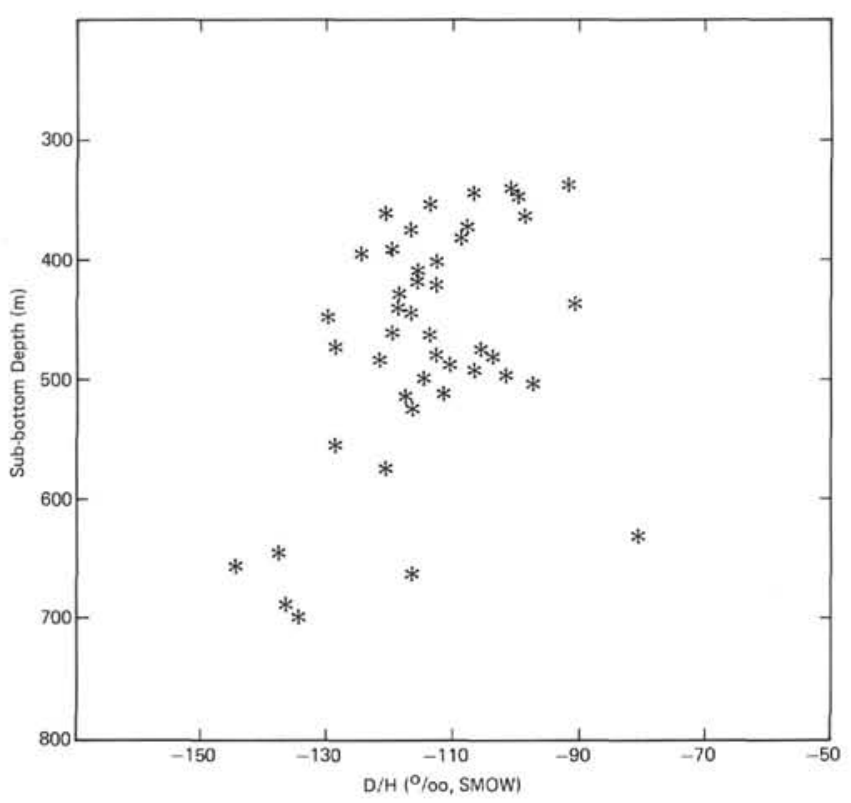

Figure 3. Whole-rock hydrogen isotope composition of basalts from Hole 417D.

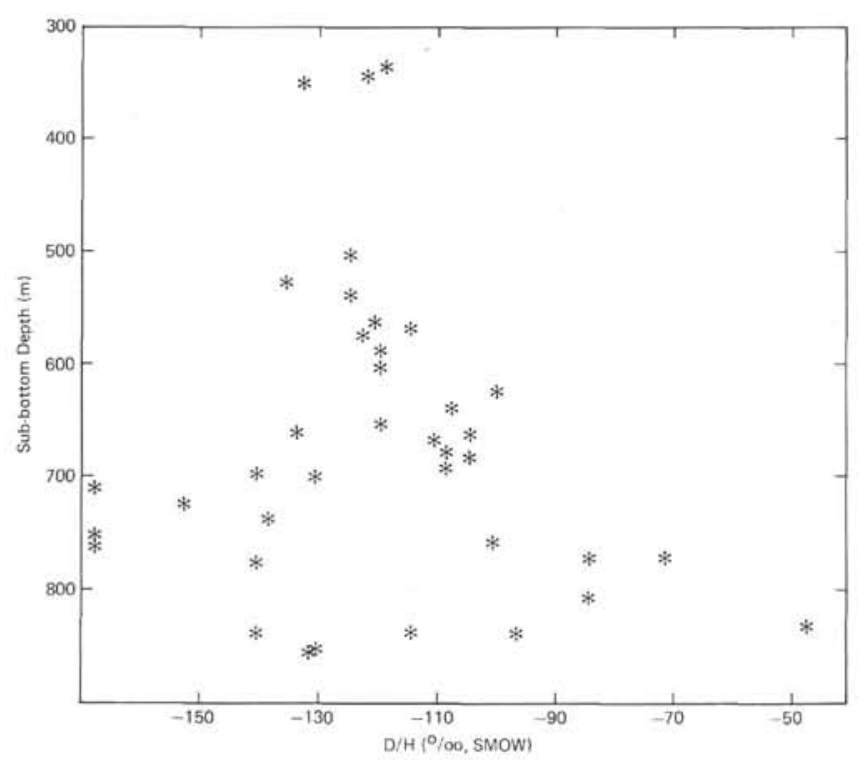

Figure 4. Whole-rock hydrogen isotope composition of basalts from Hole $418 \mathrm{~A}$.

\section{Mineral Data}

Plagioclase-phenocrysts and clinopyroxene-phenocrysts as well as (titano-) magnetites from the groundmass have been separated. Figure 6 shows a histogram of all mineral and whole-rock $\delta^{18} \mathrm{O}$-data.

All separated minerals are lower in their ${ }^{18} \mathrm{O} /{ }^{16} \mathrm{O}$-ratios than the whole rocks because of ${ }^{18} \mathrm{O}$-rich clays which are present in nearly all samples. Oxygen isotope fractionations of 2 to $2.7 \%$ between the feldspar and the magnetites have been measured on more than 90 per cent of the samples. One sample yields a higher fractionation of $3.6 \%$. Equilibrium temperatures of $1150^{\circ}$ to $970^{\circ} \mathrm{C}$ can be calcu-

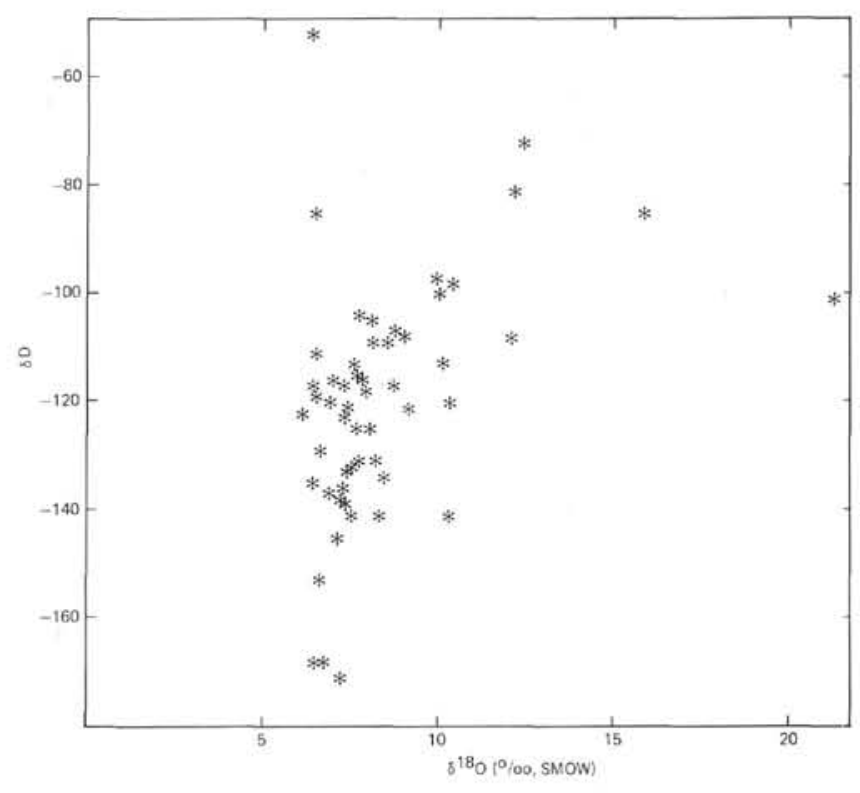

Figure 5. Plot of $\delta^{18} \mathrm{O}$ (whole rock) versus $\delta D$ (whole rock) for samples from Legs 51-53.

lated for these ${ }^{18} \mathrm{O}$ fractionations (Bertenrath et al., 1973; Bertenrath and Friedrichsen, in preparation; O'Neil and Taylor, 1967).

Pyroxenes are partly in O-isotope equilibrium with the plagioclases and the magnetites. However, there are some exceptions from isotope equilibrium between plagioclase and clinopyroxene. In these samples, lower $\delta^{18} \mathrm{O}$-values have been measured on plagioclases. Low ${ }^{18} \mathrm{O}$-fractionations of $+0.2 \%\left(\delta^{18} \mathrm{O}\right.$-plagioclase $-\delta^{18} \mathrm{O}$-pyroxene $)$ and even negative isotope-fractionations (reversals) between these phases were analyzed (Figure 7). Since, in these samples, the plagioclase differs from the mean $\delta^{18} \mathrm{O}$ value of the plagioclases which are in equilibrium, we can conclude that the plagioclases have exchanged the $\mathrm{O}$-isotopes with sea water probably in a subsolidus reaction. However, thin sections of these plagioclases (Figure 8) do not show any traces of this reaction (see also Taylor, 1974).

\section{CONCLUSIONS}

Oxygen isotope data of oceanic crust samples of Legs 51 through 53 have shown that nearly all basalts have interacted with sea water. At least 5 weight per cent of sea water oxygen has reacted with the basalts at low temperatures. There is no relationship between the depth of the recovered samples and the amount of sea water which was present during the exchange reaction. Rocks with high $\delta^{18} \mathrm{O}$-values of $+22.5 \%$ have been found at a depth of about 400 meters within the basement. Low-temperature alteration processes are confirmed by the $\mathrm{D} / \mathrm{H}$ data of the $\mathrm{OH}$-bearing minerals.

The amount of low-temperature alteration (within our statistical error) is equivalent in young oceanic crust from Legs 37,45 , and 46, and in the old crust from Leg 51-53. Circulation of hydrothermal fluids probably only happens near the ridge zones. 


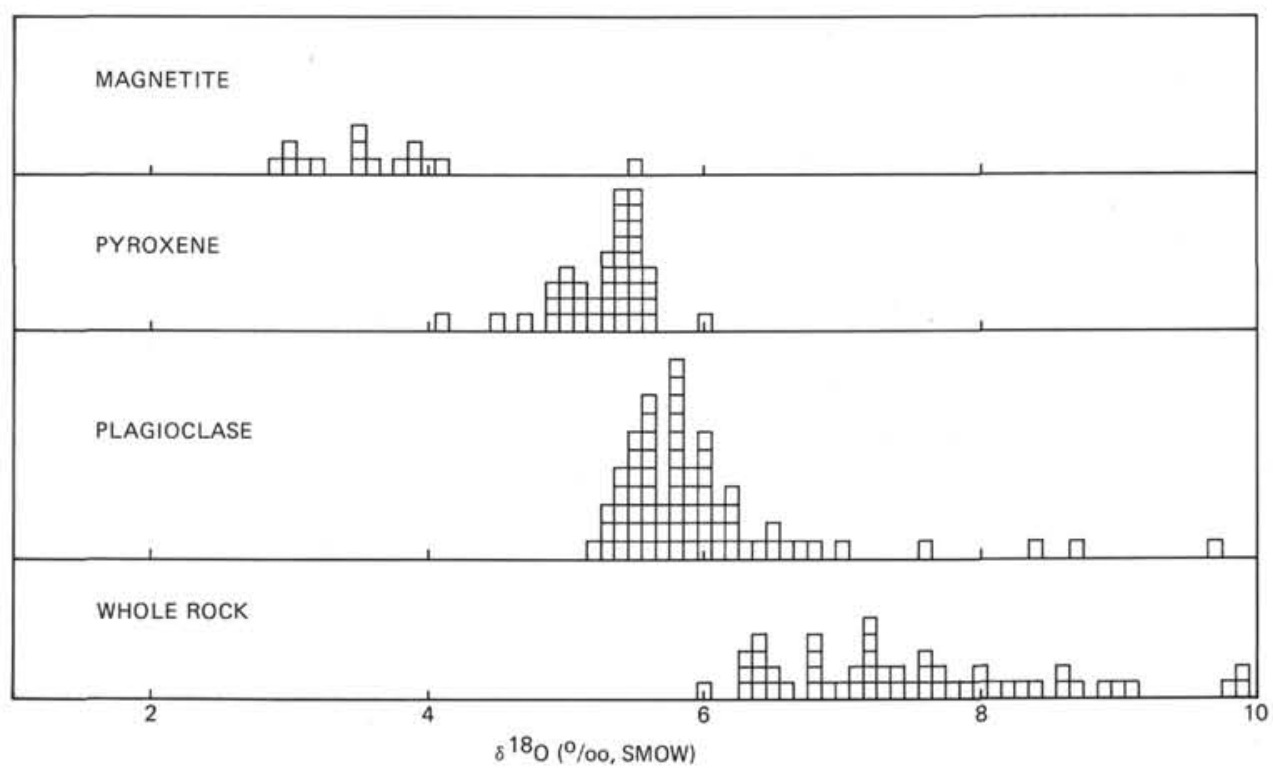

Figure 6. Oxygen isotope composition of whole-rock samples and separated minerals from Legs 51-53.

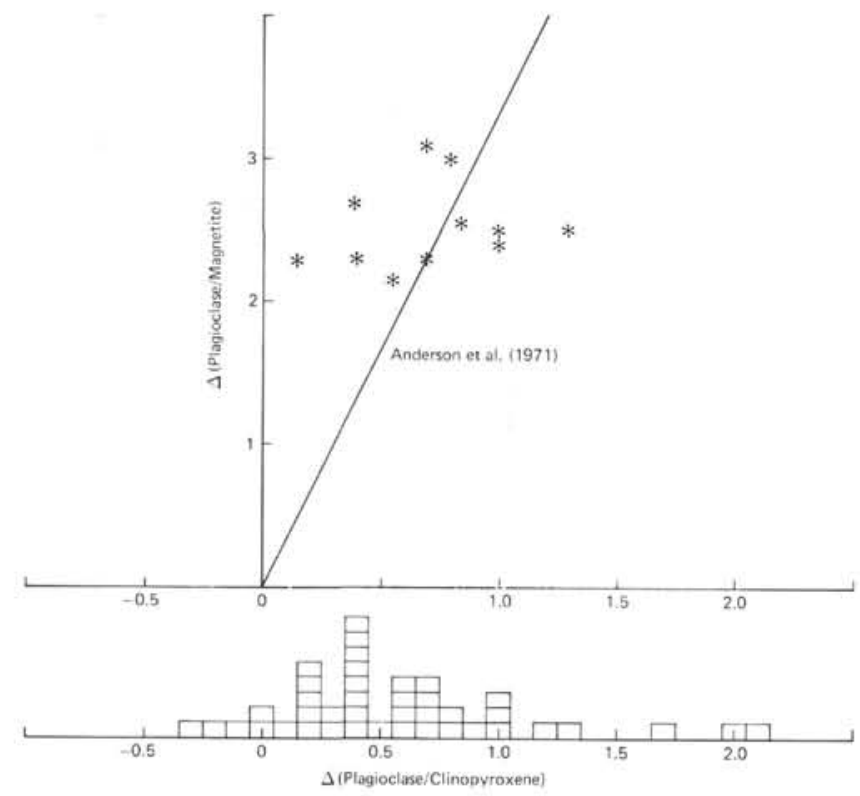

Figure 7. Plot of $\Delta$ (plagioclase/magnetite) versus $\Delta$ (plagioclase/pyroxene) and a histogram of all $\Delta$ (plag/pyrox) values. Concordancy line after Anderson et al., 1971.

\section{REFERENCES}

Anderson, A. T., Clayton, R. M., and Mayeda, T. K., 1971. Oxygen isotope thermometry of mafic igneous rocks, J. Geol., v. 79 , p. $715-729$.

Bertenrath, R. and Friedrichsen, H., in preparation. Oxygen isotope geochemistry in the system iron oxide water.

Bertenrath, R., Friedrichsen, H., and Hellner, E., 1973. Die Fraktionierung der Sauerstoffisotope ${ }^{16} \mathrm{O}$ und ${ }^{18} \mathrm{O}$ im System Magnetit/Wasser, Fortschr. Mineral., v. 50, p. 6.

Hoernes, S. and Friedrichsen, H., 1977. Oxygen isotope investigations of rocks of Leg 37. In Aumento, F., Melson, W. G., et al., Initial Reports of the Deep Sea Drilling Project, v. 37: Washington (U.S. Government Printing Office), p. 603-606. , 1978. ${ }^{18} \mathrm{O} /{ }^{16} \mathrm{O}$ and $\mathrm{D} / \mathrm{H}$ investigations on basalts of Leg 46. In Dmitriev, L., Heirtzler, J., et al., Initial Reports of the Deep Sea Drilling Project, v. 46: Washington (U.S. Government Printing Office), p. 253-256.

Hoernes, S., Friedrichsen, H., and Schock, H. H., 1978. Oxygenand hydrogen-isotope and trace-element investigations on rocks of DSDP Hole 395A, Leg 45. In Melson, W. G., Rabinowitz, P. D., et al., Initial Reports of the Deep Sea Drilling Project, v. 45: Washington (U.S. Government Printing Office), p. 541-550.

Muehlenbachs, K., 1977. Oxygen isotope Geochemistry of DSDP Leg 37 rocks. In Aumento, F., Melson, W. G., et al., Initial Reports of the Deep Sea Drilling Project, v. 37: Washington (U.S. Government Printing Office), p. 617-619.

Muehlenbachs, K. and Clayton, R. N., 1972. Oxygen isotope studies of fresh and weathered submarine basalts, Canadian $J$. Earth Sci., v. 9, p. 172-185.

, 1976. Oxygen isotope composition of the oceanic crust and its bearing on sea water, J. Geophys. Res., v. 81, p. 4365-4369.

O'Neil, J. R. and Taylor, H. P., 1967. The oxygen isotope and cation exchange of feldspars, Am. Mineralogist, v. 52, p. 1414-1437.

Suzuoki, T. and Epstein, S., 1976. Hydrogen isotope fractionation between $\mathrm{OH}$-bearing minerals and water, Geochim. Cosmochim. Acta, v. 40, p. 1229-1240.

Taylor, H. P., 1974. Oxygen and hydrogen isotope evidence for large-scale circulation and interaction between ground waters and igneous intrusions, with particular reference to the San Juan volcanic field, Colorado. In Hofmann, A. W., Giletti, B. J., Yoder, H. S., and Yund, R. A. (Eds.), Geochemical transport and kinetics: Washington (Carnegie Inst. of Washington).

Wolery, T. J. and Sleep, N. H., 1976. Hydrothermal circulation and geochemical flux at mid-ocean ridges, J. Geol., v. 84, p. 149-275. 


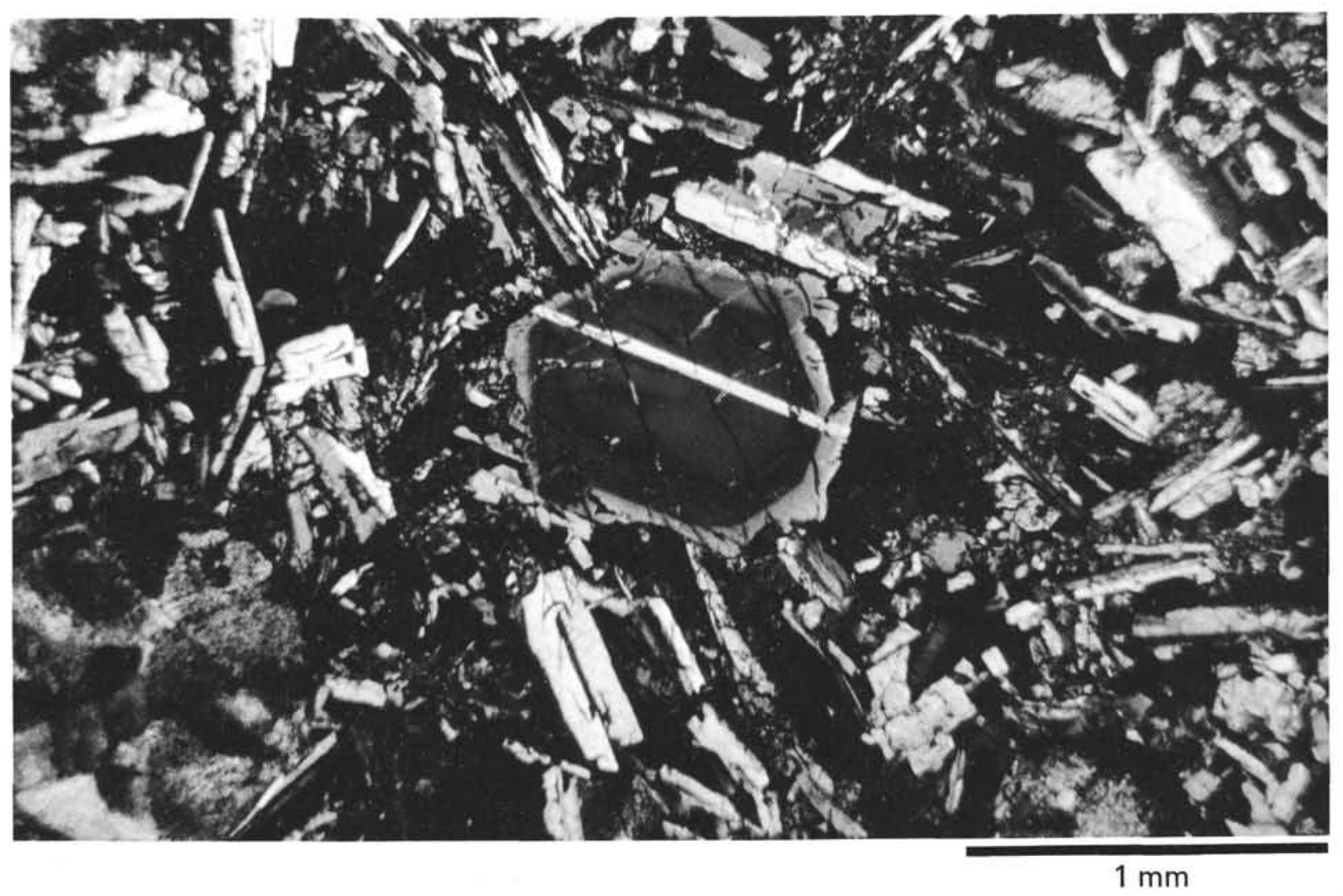

Figure 8. Photomicrograph of zoned plagioclase depleted in ${ }^{18}$ O. Sample 417D-32-2, 34-39 cm. 